\section{Huijarisyndrooma - toimijuuden ja pystyvyyden syvä särö}

Ekman, Tiina (2018). Huijarisyndrooma. Miksi en usko itseeni (vaikka olen oikeasti hyvä). Minerva Kustannus. 218 sivua.

"HERRANJUMALA, TÄLLE ON nimikin, joku muukin ajattelee näin. Vaikka ihmiset ovat sanoneet minulle, ettei tuo ole totta, silti ajattelen, että ne eivät vain huomaa”. Näin siteerataan Huijarisyndrooman takakannessa kirjaan haastateltua naista. Sitaatti kuvaa ytimekkäästi ilmiöön sisältyvää häpeän ja piilottelun ulottuvuutta sekä sisäisen ja ulkoisen todellisuuden voimakasta ristiriitaa.

Tiina Ekman määrittelee: "Huijarisyndroomaksi kutsutaan sisäistä tunnetta, ettei kaikista onnistumisistaan huolimatta usko osaavansa oikeasti. Tuntee olevansa feikki [--] Itse sen tietää, ja sitten vain odottaa, milloin muu maailma oivaltaa saman. Kokemukseen liittyy ajatus, että onnistumiset ovat onnenkantamoisia tai ylettömän suurten ponnistusten tulosta."

Huijarisyndrooma tai huijariilmiö luokitellaan ahdistusoireeksi, joka liittyy suoriutumiseen, osaamiseen ja minäkuvaan. Kyse on myös piilottelusta, häpeästä ja paljastumisen pelkäämisestä.

Tutkijat ovat erimielisiä siitä, onko huijari-ilmiötä syytä erottaa omaksi ilmiökseen ahdistusoireiden joukossa. Siitä ei anneta varsinaista diagnoosia, mutta sille on kehitetty useita testejä. Huijariksi itsensä kokevalla on tunne siitä, että oma asema ja saavutukset perustuvat osaamisen ja työnteon sijasta valheelliseen asiantilaan; outoon sattumaan tai joskus suhteettomaan raadantaan. 'Huijari' - kirjassa käytetään tätä termiä, isolla alkukirjaimella - ei omista menestystään tai osaavuuttaan. Huijarisyndrooma on siis pystyvyyden ja toimijuuden särö.

\section{JATKUVA AHDISTUS JA KUORMITUS}

Kun sisäinen ja ulkoinen todellisuus ovat ristiriidassa, vaaditaan erityisiä strategioita ristiriidan käsittelyyn. Huijarilla lähtökohta on aina itsen epäily - jollakulla muullahan se voisi olla vaikkapa toisten syyttäminen. Huijari-ilmiötä ruokkivat persoonassa vaativuus, omien tunteiden ohittaminen, perfektionismi ja herkkyys ahdistua.

Ilmiöön liittyy kehämäisiä ajatteluketjuja, jotka uusintavat sitä, vaikka jokin, esimerkiksi toisten antama kiitos, sitä haastaisi. Ekman esittelee näitä ajattelukehiä havainnollisesti. Huijari-ilmiöön kietoutuu toimintamalleja, kuten vetkuttelu tai perfektionismi, jotka riistävät ponnistelulta palkitsevuuden. Huijarisyndrooma tuottaa siten jatkuvaa ahdistusta ja kuormitusta, aina työuupumukseen ja depressioon asti.

Ekman kuvaa perhedynamiikan mekanismeja, joilla huijari-

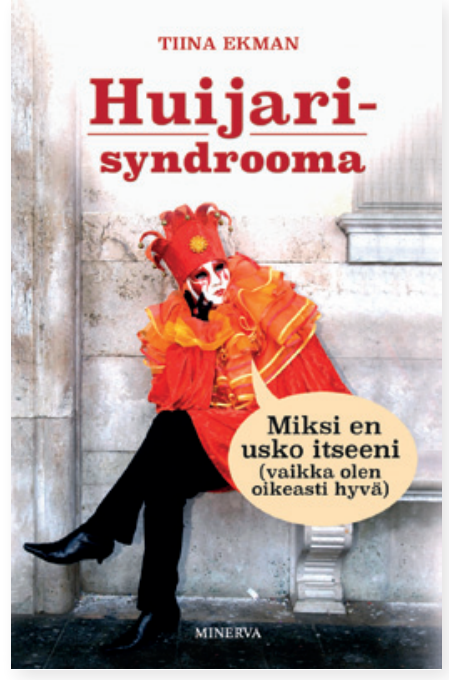

syndrooma rakentuu. Se ponnistaa tunnekylmyydestä, turvattomuudesta, epämääräisyydestä, paradoksaalisista odotuksista ja kohtuuttomuuksista lapsuuden perheessä. Se voi rakentua myös tilanteesta, jossa lapsen osaamiseen suhtaudutaan näkymättömänä ja itsestään selvänä. Suhde taitojen, ponnistelun, motivaation ja onnistumisen välillä menee jotenkin rikki, ja ongelma silautuu häpeällä.

Ilmiön tutkimus on pisimmällä Yhdysvalloissa. Termin kehitti 1970-luvulla terapeutti ja psykologian tutkija Pauline Rose Clance. Tutkimusten mukaan ilmiö esiintyy erityisesti akateemisesti koulutetuilla niin kutsutuilla uranaisilla, vaikka ei yksinomaan heillä. Se on liitetty myös yliopistoympäristöihin, sekä jatko-opiskelijoiden että henkilökunnan kokemukseen.

Naisten huijarisyndrooma kytketään teoksessa myös heidän yhteiskunnalliseen tilanteeseensa; ristiriitaan, joka rakentuu naisen perhe- ja työhistoriaan sukupuolten 


\section{ILMIÖ ESIINTYY ETENKIN}

\section{AKATEEMISESTI KOULUTETUILLA}

URANAISILLA.

epätasa-arvon ja naisiin kohdistuvien mahdottomien odotusten myötä. Huijari-ilmiö on yksi mahdollinen psykologinen vastaus tällaiseen tilanteeseen: aggressio, jota mahdottomat tilanteet herättävät, kohdistuu vaativuutena ja armottomuutena itseen.

\section{TIIVIS TIETOPAKETTI JA ITSEAPUA}

Huijarisyndrooma on nopealukuinen, kompakti tietokirja, joka tarjoaa tutkimusperustaisen ajantasaisen kuvan ilmiöstä. Kirjoittaja on ahdistushäiriöihin erikoistunut psykologi ja psykoterapeutti. Hän on kirjaa varten haastatellut huijarisyndrooman kanssa eläviä. Kaikki haaviin tulleet haastateltavat olivat naisia.

Huijari-ilmiö on pirullinen siksi, että se jää usein piiloon muhimaan vuosiksi. Ulospäinhän näkyy vain hyvä työn jälki. Jos Huijari kertoo raskaista tuntemuksistaan, häneen saatetaan suhtautua ärtyneesti tai huvittuneesti. Tämä piilottaa hänet syvemmälle huijarikuoreensa.

Huijariajattelun horjuttaminen vaatiikin enemmän kuin kehuja tai menestystä. Kertaoivallus tai toisten vakuuttelu ei vielä muuta vuosien aikana rakentunutta strategiaa. Huijariajattelusta pääsee, kuten muistakin ahdistavista ja häpeää tuottavista ajatusvääristymistä: tietoisella vähittäisellä muutostyöllä, itsen ja toisten myötätunnolla sekä vaihtoehtoisen toiminnan harjoittelulla. Moni hyötyy terapiasta, jotakuta voi auttaa oma tiedostava pohdinta tai uudenlainen elämäntilanne.

Kirjasta noin neljännes käsittelee erilaisia kognitiivisen ja käyttäytymisterapian nykysuuntauksista tuttuja tietoisuustaitoja. Autetaan asettumaan havainnoivaan ja myötätuntoiseen suhteeseen oman mielen kanssa ja valitsemaan realistisempia tulkintoja ja toimintatapoja suhteessa oman mielen tapahtumiin ja sosiaalisiin tilanteisiin, kuten vaikeuksiin työssä tai palautteeseen. Kirjan lopussa on lyhyt testi, jonka avulla voi pohtia, onko omassa ajattelussa huijari-ilmiön piirteitä.

Huijarisyndroomassa on tiiveydestään huolimatta toisteisuutta, ja pari hyvin ohueksi jäänyttä lukua. Teoksen jäsentelyä olisikin voinut hieman vielä miettiä. Puutteistaan huolimatta kirja on oivallinen, selkeäsanainen johdatus aiheeseen. Näkökulma on psykologinen ja realistisen toiveikas: huijari-ilmiön vaikutusta elämässään voi vähintäänkin lieventää.

MITEN HUIJARISYNDROOMAA PURETAAN?

Mietin sekä itse huijariajattelus- ta kärsivänä että huijari-ilmiöön ajoittain törmäävänä työnohjaajana, mitkä kulttuuriset tekijät mahdollistavat, että yksilön suhde tekemisiinsä kehittyy huijarisyndroomaksi. Liittyykö se lähinnä niihin tiedon ja taidon alueisiin, jossa tehtävät ja osaaminen ovat vaikeasti mitattavia ja tulkinnanvaraisia? Se on monenlaisen asiantuntijatyön ja luovan työn riesa. Yliopistotyössä huijarisyndrooma muhinee siksi, että siinä yhdistyvät mahdottomat tavoitteet, jatkuva kilpailu ja eräänlainen kutsumuseetos.

Mietin myös, millaiset työ- ja oppimisympäristöt tukisivat realistisen pystyvyyden kehittymistä. Lukemani perusteella mieleeni tulee kolme aluetta, jolta lähtisin ratkaisua hakemaan. Ensiksikin luonteva kiittävä palaute toistuvana osana työskentelyä. Toiseksi suorituksen, työprosessin ja onnistumisen kriteerien välisen suhteen purkaminen ja demystifiointi. Kolmanneksi vertaistukea sisältävien keskustelevien tilojen luominen.

Huijarisyndrooma ei ole pikkujuttu tai turhaa mielenpahoittamista. Se on iso elämänkulkuja muotoileva toimijuuden särö.

SANNA VEHVILÄINEN

$\mathrm{KT}$, dosentti, kouluttaja, työnohjaaja 